\title{
Libraries R 4 Learning: Supporting the Curriculum for Excellence in Aberdeenshire
}

\author{
Sue Cromar
}

\begin{abstract}
In April 2009, Aberdeenshire Library and Information Service (ALIS) was awarded $£ 10,000$ by the Scottish Library and Information Council (SLIC) to develop and deliver a programme of advocacy - designed to inspire and encourage effective, equal working partnerships between librarians and teachers in local secondary schools. All materials created over the lifetime of this project will be published under a Creative Commons licence, and made available to be used and adapted by library professionals across Scotland. This article outlines some of the ideas and observations that fed into our successful proposal, and sets out our plans for achieving key outcomes of the Libraries R 4 Learning project.
\end{abstract}

\section{Context}

ALIS is an integrated service, supporting both school and public libraries across Aberdeenshire from its headquarters in Oldmeldrum. Operations are managed by a team of Network Librarians based in Aberdeenshire's seventeen secondary schools, or Academies. These professionals have responsibility for school library services, and for all public library branches in their catchment area. The Network Librarians are supported by a central team of professional staff, including a Young People's Services Librarian, a Primary Schools' Librarian and an Information Literacy Librarian.

Our planned approach to information literacy development across Aberdeenshire is defined in our current strategy document:

"to support the integration of core, transferable information and critical literacy skills within formal and informal learning experiences, supporting Aberdeenshire's citizens of all ages to become effective lifelong learners"

(ALIS, 2009).

\section{Sue Cromar}

Sue Cromar is Information Literacy Librarian for Aberdeenshire Library and Information Service, and an active participant of Aberdeenshire's Literacy Steering Group.

Email: suecromar@googlemail.com 
Over the last ten years, our librarians have used centrally produced workbooks and other support materials with first year pupils, covering a variety of basic information skills. By making these materials available for use in every Academy, our intention had been to ensure that Aberdeenshire's pupils received the same breadth of instruction, whichever school they attended. However, while some Network Librarians were allocated several hours (generally from timetabled English lessons) to work through the materials with pupils, others were given very little time and were restricted to covering the essentials of Dewey, alphabetical order and library orientation.

With few exceptions, information literacy sessions had been delivered as one-off events, usually confined to the first few weeks of S1, and were rarely reinforced or developed as pupils progressed through the school. This was very much a bolton approach, often bearing little relation to the rest of the curriculum. Not surprisingly, librarians reported that pupils often seemed unable to relate what they had learned - way back at the start of their first term - to the topic investigations or research tasks set by their class teachers.

Some Academies had already begun to work towards a more effective model, where information and critical literacy skills are situated within meaningful classroom activities or real-life situations across all subjects and year groups, and Network Librarians are full partners in the development and delivery of learning materials. Our strategy is to develop this approach across all schools in Aberdeenshire.

\section{Perceptions}

Since coming into post as Information Literacy Librarian in October 2008 I've visited all our Academies, have seen some innovative and imaginative practice around information literacy support, and witnessed some inspirational teacher librarian partnerships in action. However, the impact of information literacy interventions has varied greatly across Aberdeenshire. To take our new strategy forward, Network Librarians must overcome barriers grounded in outdated and inaccurate - but deeply rooted - perceptions around the role of school librarians in learning and teaching. These professionals are often cast firmly in the role of support staff, considered to be serving a purely functional role in the school, and unlikely to be taken seriously as potential collaborators.

\section{The Curriculum for Excellence - an ideal opportunity for partnership}

Scottish schools are in the process of implementing the Curriculum for Excellence, a new and transformational approach to learning and teaching which aims "to ensure that all the children and young people of Scotland develop the attributes, knowledge and skills they will need if they are to flourish in life, learning and work, now and in the future" (Learning and Teaching Scotland, 2009a). The curriculum has been redesigned to provide pupils with a broad general education and places a strong emphasis on the development of skills as "a sound basis for their development as lifelong learners in their adult, social and working lives" (Learning and Teaching Scotland, 2009b). Cross-cutting themes of health and wellbeing, literacy and numeracy ensure that skills for learning and life are embedded within all subject areas from preschool onwards. 
For the first time in their professional lives, many secondary school teachers are being asked to take account of pupils' literacy experiences in their own subject area. Scientists and mathematicians, for example, are faced with the problem of how to develop pupils' reading, writing, listening and talking experiences in their laboratory or classroom. They are not expected to manage these changes in isolation, however, but in partnership with "a range of practitioners, including those who work in school library resource centres, who make an enormous contribution to the development of the literacy skills of children and young people" (Learning \& Teaching Scotland, 2009c). Teachers are actively encouraged to team up with professionals beyond the classroom to create real and relevant experiences for their pupils which will help them develop and apply literacy skills in a wide range of contexts.

School librarians across Scotland recognise that this period of change presents a golden opportunity to forge meaningful, effective working partnerships with teaching staff - to "get out there and start knocking on doors", become "part of the solution". (Blane, 2009). The Libraries R 4 Learning project was conceived to support our local Network Librarian team to do just that. We are also keen to share good practice with schools and Local Authorities elsewhere.

\section{Project aims}

Our core aim is to raise the profile of Network Librarians as partners in developing and delivering experiences and outcomes within and beyond the classroom, especially those which relate to literacy across the curriculum. 'Literacy across learning' outcomes are organised within the headings of reading, writing, listening and talking, then by further subdivisions which include finding and using information, and understanding, analysing and evaluating. A number of these outcomes and experiences include statements which relate directly to information literacy, for example:

"To help me develop an informed view, I am exploring the techniques used to influence my opinion. I can recognise persuasion and assess the reliability of information and credibility and value of my sources". (LIT 3-18a)

".... I recognise when it is appropriate to quote from sources and when I should put points into my own words. I can acknowledge my sources appropriately”. (LIT 3-25a)

(Learning and Teaching Scotland, 2009d)

We will bring academics and school library staff together for planning and development events designed to get teaching staff reflecting on the ways in which librarians can support their work with pupils, and on how they could collaborate to develop learning experiences. It is essential that we develop the skills and confidence of our Network Librarians as advocates of their service - and themselves as competent professionals - and improve their working knowledge of the curriculum. Finally, we hope to inspire effective, equal working partnerships, established to solve common concerns around, for example, plagiarism and critical literacy skills. 


\section{Why advocacy?}

With the support of Gilian Dawson from the University of Aberdeen, our Network Librarians have already begun to look at the concepts of advocacy and relationship marketing, and how they can be applied in schools. It is not our intention to run a traditional 'here we are, we're great, come and get us' marketing campaign. Instead, we're looking at how we can nurture and sustain relationships at the 'chalk-face'. We must get across that librarians are well equipped to support their teaching colleagues through the process of integrating literacy across learning - sharing the load, saving them time, ensuring that key curriculum outcomes and experiences are met. We also aim to convey the message that information and critical literacy skills are relevant for life, not just for libraries!

\section{Project outcomes and outputs}

Training in advocacy and relationship marketing skills for our Network Librarians and Young People's Services staff has already begun. Within the next few weeks, some staff will receive multimedia production and editing training, after which we will begin to produce a bank of materials to support CPD activities in schools. Our project outputs will include a series of presentations and short multimedia clips for use with teachers, school management teams and curriculum planners. The materials will focus on the integration of information literacy skills across formal and informal learning, and everyday life situations. There will be a strong emphasis on partnership, and the added value which professional librarians can bring to planning for learning and teaching.

\section{Why multimedia?}

The production of a series of individual film clips will be one of the core outputs of this project. As librarians, we can talk passionately and at length to our teaching colleagues about the value of information skills and their place in the curriculum, but much of what we have to say is 'second hand news'. We believe it's time that our audience heard about the value of information literacy skills 'from the horse's mouth' - from learners and practitioners in the 'real world' who exploit these skills on a daily basis.

Writing on the crucial importance of advocacy in promoting the development of information literacy across learning, Peter Godwin asserts that "[we] must get the message across simply and forcefully .... using well illustrated material with punchy examples of where IL counts" (Godwin, 2009, 3). This is precisely what we hope to achieve by using multimedia to present our case. In this instance, our 'message' is the importance of information literacy skills in a range of situations, and the role that librarians can play in supporting literacy across learning. Our aim is to create something inspirational, memorable, thought-provoking and engaging - and flexible, so that materials can be used as a whole or as individual sound-bites.

Video clips will include interviews with academics, school and university librarians, curriculum managers, learners, employers, and professionals such as journalists, scientists and health workers. Along with any other documentation we produce over the life of this project, all video clips will be made available to download as Creative Commons materials from the Slainte website 
(www.slainte.org.uk) - an online community for library and information professionals in Scotland - to be used as a complete package, or adapted as required by other library and information practitioners.

\section{Next steps}

From November 2009, we will plan and produce our DVD and compile other support materials for both school librarians and teaching staff. A training and development day will be held in the Spring of 2010 to bring Network Librarians together with curriculum managers and Literacy Co-ordinators from each of the Academies. The aim of the event will be to investigate practical ways in which information and critical literacy skills can be integrated within classroom practice, and how teacher-librarian partnerships could be encouraged and supported in schools. When all project training and development events have taken place, we will translate our outcomes into some guidelines for school librarians and academics relating to advocacy, partnership working and integrating literacy across learning.

The first project outputs - a set of CPD materials for use with teaching staff and curriculum managers - will be published online by the end of April 2010, followed shortly afterwards by a variety of multimedia materials. Finally, our Network Librarian team will pilot these in schools across Aberdeenshire and an evaluation will be included in our final project report. We are grateful to SLIC for giving us this opportunity to transform our service in the schools sector and hope our experiences will be of relevance and value to the rest of the Scottish library and information community and beyond.

\section{References}

Aberdeenshire Library and Information Service (2009) Draft information literacy strategy.

Blane, D. (2009) 'Librarians should get out there ... and start knocking on doors', Times Educational Supplement [online], 6 February. URL:

http://www.tes.co.uk/article.aspx?storycode $=6008405$ [accessed 22.7.09].

Godwin, P. (2009) Information literacy "sans frontieres". URL:

http://librariesofthefuture.jiscinvolve.org/files/2009/03/information-literacy-

sans-frontieres .doc [accessed 23.10.09].

Learning and Teaching Scotland (2009a) Building the curriculum 4: skills for learning, skills for life and skills for work. URL:

http://www.ltscotland.org.uk/curriculumforexcellence/buildingthecurriculum/guid ance/btc4/index.asp [accessed 9 .11.09].

Learning and Teaching Scotland (2009b) Curriculum for excellence purposes and aims: improving learning. URL:

http://www.ltscotland.org.uk/curriculumforexcellence/curriculumoverview/aims/i ndex.asp [accessed 23 10.09].

Learning and Teaching Scotland (2009c) Literacy across learning: principles and practice. URL: 
http://www.ltscotland.org.uk/Images/literacy across learning principles practice tcm4-540108.pdf [accessed: 23.10.09].

Learning and Teaching Scotland (2009d) Literacy: experiences and outcomes.

URL: http://www.ltscotland.org.uk/Images/literacy_experiences_outcomes_tcm4539998.pdf [accessed: 2310.09]. 